\title{
THE POTENCIAL OF INTERSTOCK USE TO REDUCE DIPLODIA DISEASE (BOTRYODIPLODIA THEOBROMAE PATH.) ON CITRUS PLANT
}

\author{
Dwiastuti Mutia Erti*, Sugiyatno Agus \\ Indonesian Citrus and Subtropical Fruits Research Institute, Batu, Indonesia \\ *E-mail: mutiaed@gmail.com
}

\begin{abstract}
Botryodiplodia theobromae Path. has caused a damage to stems and death of citrus plants in 22 production centers in Indonesia. The purpose of this research is to determine the potential use of rootstock and interstock in inhibiting the diplodia disease. The research was conducted at the screen house of Indonesian Citrus and Subtropical Fruits Research Institute from July to December 2016. There are 24 treatment combinations consisting of 8 interstocks on 3 commercial citrus varieties. The results showed that the scion of sweet-lime combined with the interstock of Volkameriana, Troyer citrange, and Kanci have the smallest area of disease exposure $\left(0 \mathrm{~cm}^{2}\right)$. Therefore, this combination has the highest potential to inhibit the rot of orange B theobromae stem (there is no symptom = tolerant). The scion of Keprok Batu 55 with the interstock of Carrizo citrange, Swingle citrumello, Poncirus trifoliata, and the scion of sweet lime on Carrizo citrange, Poncirus trifoliata have the least potential to inhibit the rot of the stem compared to other interstock treatments (moderate = slightly resistant). The plants combined with Volkameriana interstock are taller than the other while the plants combined with Citromello and P.trifoliata interstock have the shortest size (stunted).
\end{abstract}

\section{KEY WORDS}

Botryodiplodia theobromae, citrus, diplodia, interstock.

Extreme climate change has changed the disease status of citrus crops in Indonesia. The facts in the field show that, currently, not the Citrus Vein Phloem Degeneration (CVPD) that attacks the citrus plantation but diplodia disease. The cause of this disease is Botryodiploida theobromae Path. which is synonymous to Lasiodiplodia theobromae (Griff. \& Maubl (Juan et al., 2013). Diplodia disease is very substantial because it can kill plants even in the form of seeds or already in the form of mature plants.

The symptoms of the disease are marked with wet spots on the stems, branches, and twigs, followed by broken skin plants secreting a gum like golden-brown glue. Diplodia is not a new disease in citrus crops, its attack has been detected years ago. However, at that time, diplodia is considered not as harmful as CVPD. In 2000, Semangun reported that diplodia disease had attacked citrus crops in Java, Sumatra, Kalimantan, and East Nusa Tenggara. Allegedly, it is due to the climate change in 2009 that tend to be wet until now causing the disease becomes worse.

The geographical distribution of these diseases is very wide. Today, the diseases can be found in all Indonesian citrus centers of more than 22 provinces, districts, and cities. From the report of the Directorate of Plant Protection in 2010 to 2013, there were 577,678,00 citrus trees in Indonesia attacked by diplodia (processed from diplodia attack data source per year by the Directorate of Horticultural Protection 2014). This can be said that the average rate of the attack is 144,419 trees per year. Salamiah (2009) mentioned that the disease tends to attack citrus plants aged $>10$ years than the plants aged $>4$ years and 4 to 10 years. In Magetan, East Java, $85 \%$ tress from 500 ha of orange crops (Citrus grandis L) have been attacked by diplodia disease. The attack is known to be on the rate of mild to moderate attack (22-37\%). It is assumed that the transmission of this disease is through the splash of the water from the ground. Therefore, a high rainfall will accelerate the transmission of this disease. Weed-free citrus plantation will be quickly exposed to this disease as they directly struck by the rain. In contrast, a plantation that is covered with grass is relatively safer from 
the attack of the disease. The use of immature manure can also accelerate the transmission of this disease. B. theobromae fungus has a variety of host (CABI, 2007) such as citrus, chocolate, rubber, mangosteen, banana, mango, pineapple, avocado, melon, coconut, and eggplant. This fungus is also reported to attack papaya (Nishijima, 2003), jackfruit, mango, mangosteen, beans (Haggag, 2006), banana, lychee, cashew (Alam et al., 2001), coconut (Warwick et al., 1991), apple (Letham, 1989), cocoa (Mbenoun et al., 2008), and guava (Masilamani \& Muthumary, 1996).

Currently, more than $95 \%$ of citrus crops in Indonesia use the rootstock of Citrus limonia Osbeck or often called as Japansche citroen (JC) (Balitjestro 2006). JC is more preferred because it has high adaptability and compatibility with all types of oranges in Indonesia as well as resistant to drought and salinity. However, JC is susceptible to diseases such as CVPD, CTV, CEV, root rot, and diplodia (Supriyanto \& Setiono, 2006 in Sugiyatno \& Palupi 2017). To overcome the growth and resistance to disease, scientists have introduced other rootstocks such as Poncirus Trifoliata, Troyer Citrange, Carizzo Citrange, Cleopatra Mandarin, Volkameriana, Citrumello, and Flying Dragon (Hardiyanto et al. 2010 in Sugiyatno \& Palupi 2017).

Interstock is a third plant that serves to prevent the incompatibility in plants characterized by death in young plants, inhibition of plant growth, yellowing and falling leaves, as well as asymmetrical growth in rootstock and stem (Ashari, 2006). The use of interstock is expected to become a bridge connecting the rootstock and stem so that the plant will grow normally (Sugiyatno, 2013).

The research in concern to the use of interstock has been documented. The interstock of Citrumello has the potential to encourage the growth of vegetative crops. Meanwhile, Rangpur Lime, Flying Dragon, and Troyer have the potential to control plant growth. The interstock of Flying Dragon is also known to potentially stimulate the efflorescence and fertilization of Pamelo Nambangan (Susanto et al., 2010). On the rootstock of Catania 2 Volkamer Lemon, the Flying Dragon interstock will decrease the size of the plant, while on the rootstock of Davis A Trifoliate, the Flying Dragon interstock will increase the size of the plant (Nunez et al., 2011). Moreover, the use of Flying Dragon interstock on different rootstock of Star Ruby grapefruit, tangerine Mikhal, and Nova, will lead to the differences in vegetative growth (Ashkenazi et al., 1992 in Nunez et al., 2011). Izquierdo et al. (2004) stated that the use of Lemon interstock could increase the age of the plant, production, and fruit quality as well as reduce the thickness of the stem skin on the connected parts. In Malaysia, the use of interstock may inhibit the progression rate of HLB disease in citrus plants (Shokrollah et al, 2011).

The effect of interstock on the resistance of infectious diseases through plant propagation has not been studied although there are some indications that certain rootstocks such as the Trifoliata group are resistant to CTV and Phytophthora. The use of citrus seeds with interstock has several benefits such as increasing productivity and increasing resistance to certain diseases especially for stem disease (Kresdorn 1978). It is also believed to be beneficial for a high-density spacing planting system (SITARA = Sistem tanam rapat). The citrus tolerance to abiotic and biotic factors depends on many factors including the types of the rootstock, N fertilization, soil, and climatic conditions (Garcia-Sanchez \& Syvetisen 2009; Gimeno et al. 2009a; Saleh et al. 2008), as well as the interstock grafting between rootstock and stem because it can increase the growth of the plant, productive age, fruits, and quality (Gillzquierdo et al., 2004). In addition to that, it can also increase the tolerance to salinity including citrus disease that is susceptible to salinity. (Gimeno et al., 2009b). The disease that is sensitive to salinity is rotten stem disease (Phytophotora spp.) and diplodia (B. theobromae). The purpose of this research is to know the influence of seven (7) types of interstock in 3 commercial citrus varieties towards the disease of diplodia.

\section{METHODS AND MATERIALS}

The research was conducted at the screen house of Indonesian Citrus and Subtropical Fruits Research (ICISFRI) from July to December 2016. In the observation, the researchers 
used plants aged $>1$ year. The preparation of the interstock took place one year beforehand by connecting the type of interstock based on the treatment requirements $(15 \mathrm{~cm}$ from the base of the stem with a grafting incision of $1.5 \mathrm{~cm}$ followed by connecting it with the scion in accordance to the treatment that is approximately $10 \mathrm{~cm}$ above the interstock joint in the same grafting model). Then, the grafted eye is inserted and tied with an elastic plastic strap starting from below rotating upwards. After 2-3 weeks, when the grafted eye is still fresh, the plastic strap is opened.

The test plants were grown on 3-liter polybags with mixed soil and compost $(1: 1 \mathrm{v} / \mathrm{v})$. In the dry season, watering is carried out twice per week in a field capacity condition. Basic fertilizer is given in the form of NPK (15-15-15) with a dose of $20 \mathrm{~g} /$ tree plus ZA $10 \mathrm{~g} /$ tree. Then, every 2 months, ZA will be added by $15 \mathrm{~g} /$ tree. Pest or disease control is done in accordance with the condition of the plant to prevent the attack of the destructive pest on leaves. Weeding the weeds is performed every once a week and at the time of fertilization. The weeding will be done more intensively in rainy season by retracting it directly.

Twenty four combinations of interstock (Japanese citroen, Rough lemon, Carrizo citrange, citrumello, Poncirus trifoliata, volkameriana, Troyer citrange and Kanci) on 3 commercial citrus varieties (C. reticulata (Blanko) vr Keprok Batu 55, C. nobilis vr Siam Pontianak and Citrus kumquat vr Kanci) (table 1) were used. Each treatment was repeated for 2 times and each replication consists of 1 test plant. The $B$. theobromae isolate used for the source of inoculum test was derived from the collection of Magetan Phytopathology Laboratory.

The source of inoculum used is in the form of a pathogen-infected stem that is then transmitted to the treatment plant by inserting it into a healthy stem and fastened with plastic. The outside part is sprayed with sterile aquades once in every three days to keep the moisture of the plants. The stems infected are known from the Pamelo types. The manufacture of the inoculum source is infected by the modification of method from Putra et al., (2013) by taking a healthy $1 \mathrm{~cm}$ citrus stem and then sterilized by using $70 \%$ alcohol for 1 minute, chlorox for 1 minute, and sterile aquades for 1 minute. Each of that treatment is repeated twice. The inoculum source was incubated in PDA (Potato Dextrose Agar) which had a full colony of $B$. theobromae. The incubation was performed for a week until the stem showed such infected symptoms that are browned and covered with mycelium pathogen and issued a yellow liquid exudate (Figure 1).
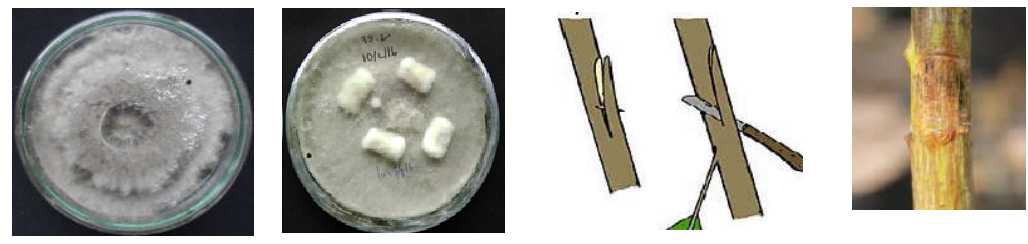

Figure 1 - The stages of $B$. theobromae inoculation process in the test plant:

a) Isolate purification $\mathrm{Mg} 39.2$ from pamelo, b) healthy twigs isolation in pure culture of fungal isolates, c) infected twigs insertion on test plant, d) successful inoculation indicator marked by the occurrence of diplodia symptoms

The observation parameters are:

(a) The percentage of successful inoculation and incubation period. The percentage of successful B.theobromae inoculation is observed based on the emergence of disease symptoms in the inoculated plant such as wet decay and gum secretion. The period of the pathogen incubation is the time between inoculation of the pathogen to the initial appearance of symptoms in citrus plant stems. The observations were performed on the infected plant stems. The monitoring of the symptoms is based on Putra et al., (2013) that there is a skin peeling on the stem, a discoloration to brown, a moisture on the surface of wounds, and a discharge of thick-brown liquid from the source of infection (gum or blendok). The average incubation data shows the time span between the inoculation process until the occurrence of the symptoms. The observations are made once every 2 days until the symptoms appear. 
Table 1 - The list of interstock and scion combination

\begin{tabular}{|l|l|l|}
\hline Combination & Interstock & Scion \\
\hline Combination 1 & Rootstock Japansche citroen (JC) - Control & C. reticulata (Blanko) vr Keprok Batu 55 \\
\hline Combination 2 & Rootstock Japansche citroen (JC) - Control & C. nobilis vr Siam Pontianak \\
\hline Combination 3 & Rootstock Japansche citroen (JC) - Control & C. aurantifolia vr Sweet Lime \\
\hline Combination 4 & Carrizo citrange & C. reticulata (Blanko) vr Keprok Batu 55 \\
\hline Combination 5 & Carrizo citrange & C. nobilis vr Siam Pontianak \\
\hline Combination 6 & Carrizo citrange & C. aurantifolia vr Sweet Lime \\
\hline Combination 7 & Citrumello & C. reticulata (Blanko) vr Keprok Batu 55 \\
\hline Combination 8 & Citrumello & C. nobilis vr Siam Pontianak \\
\hline Combination 9 & Citrumello & C. aurantifolia vr Sweet Lime \\
\hline Combination 10 & Poncirus trifoliata & C. reticulata (Blanko) vr Keprok Batu 55 \\
\hline Combination 11 & Poncirus trifoliata & C. nobilis vr Siam Pontianak \\
\hline Combination 12 & Poncirus trifoliata & C. aurantifolia vr Sweet Lime \\
\hline Combination 13 & Volkameriana & C. reticulata (Blanko) vr Keprok Batu 55 \\
\hline Combination 14 & Volkameriana & C. nobilis vr Siam Pontianak \\
\hline Combination 15 & Volkameriana & C. aurantifolia vr Sweet Lime \\
\hline Combination 16 & Rough lemon & C. reticulata (Blanko) vr Keprok Batu 55 \\
\hline Combination 17 & Rough lemon & C. nobilis vr Siam Pontianak \\
\hline Combination 18 & Rough lemon & C. aurantifolia vr Sweet Lime \\
\hline Combination 19 & Troyer citrange & C. reticulata (Blanko) vr Keprok Batu 55 \\
\hline Combination 20 & Troyer citrange & C. nobilis vr Siam Pontianak \\
\hline Combination 21 & Troyer citrange & C. aurantifolia vr Sweet Lime \\
\hline Combination 22 & Citrus kumquat vr Kanci & C. reticulata (Blanko) vr Keprok Batu 55 \\
\hline Combination 23 & Citrus kumquat vr Kanci & C. nobilis vr Siam Pontianak \\
\hline Combination 24 & Citrus kumquat vr Kanci & C. aurantifolia vr Sweet Lime \\
\hline & & \\
\hline
\end{tabular}

(b) The severity of disease symptoms. A wide observation of the symptoms is done on the infected stem. The observation was conducted once every 7 days until the symptoms appear by measuring vertically $(\mathrm{v})$ and horizontally $(\mathrm{h})$ on the infected parts. The area of the infection symptoms $\left(\mathrm{cm}^{2}\right)$ is known by multiplying $(\mathrm{v})$ and $(\mathrm{h})$. The observation was carried out 49 days after inoculation.

(c) Plant growth:

- Plant height. Plant height is measured from the edge of the joint (attachment/grafting) between the scion and the interstock to the growing point. The observation was done once every two weeks.

- Stem diameter. The measured stems include rootstock and scion. The stem was measured in diameter by using the sliding term. The measured stems were marked with a black waterproof pen. This observation was conducted once a month.

The data of the observation will be analyzed by using the Analysis of Variance (ANOVA) on $5 \%$ level. If there is a significant difference, the results will be tested further by using DMRT Test (Duncan Multiple Range Test) on 5\% level.

\section{RESULTS AND DISCUSSION}

The Percentage of Successful Inoculation and Incubation Period. Based on the results of the study, the percentage of infected plant inoculation showed that almost all inoculation was successful (100\%) except in the combination of JC/volkameriana/Siam Pontianak, JC/Citrus jambhiri vr RL/Siam Pontianak, JC/Citrus jambhiri vr RL/sweet lime, JC/Citrus kumquat vr Kanci/Siam Pontianak, and JC/Citrus kumquat vr Kanci/sweet lime. Scion varieties of Keprok Batu 55 with all interstock combinations produce $100 \%$ of infected plants. The infection of diplodia characterized by stem peels, discoloration, or gum secretion begins to appear within 12 to 25 days after the varied inoculation in between treatments. The incubation period was not found in 4 treatment combinations because the plants showed no symptoms such as in the treatment 1). JC/volkameriana/C. aurantifolia vr Lemon Sweet; 2). JC/Troyer citrange/C reticulata vr K.Batu 55; 3). JC/Troyer citrange/C. aurantifolia vr Lemon Sweet; 4). JC/Citrus kumquat vr Kanci/C. aurantifolia vr Lemon Sweet (table 2). Previous studies which brought similar inoculation methods on different combinations of rootstocks 
and different inoculums proved that the incubation period is varied between 9 to 39 days (Dwiastuti, et al., 2017, Putra et al. 2013 and Salamiah et al. (2008). The incubation of B.theobromae in grape and pear plants was reported fairly rapidly in the study (Verma et al. 2010) which is 3 to 7 days after inoculation (HIS or hari setelah inokulasi). The incubation period and symptoms arising from $B$. theobromae infection depend on the number and pathogenic virulence, plant species, and climatic conditions (Shahbaz et al., 2009 Adandonon 2014). The isolates of B.theobromae from the inoculated citrus on rubber have an incubation period of 14 days. After the inoculation, it is known the the isolates become faster than the isolates from mango, papaya, cashew, or avocado (Febiyanti, et al., 2017). The pathogens can develop well at $80 \%$ of moisture especially in high rainfall conditions in between the temperatures of 25 to $30^{\circ} \mathrm{C}$ (Shah et al., 2010; Khanzada et al., 2006).

Table 2 - The percentage of successful inoculation and incubation period on the treatment of rootstock, interstock, and scion combination

\begin{tabular}{|c|c|c|c|c|}
\hline Combination & Interstock & Scion & $\begin{array}{l}\text { Successful inoculation } \\
\text { percentage }(\%)\end{array}$ & $\begin{array}{l}\text { The incubation } \\
\text { period (days) }\end{array}$ \\
\hline Combination 1 & $\begin{array}{l}\text { Rootstock Japansche } \\
\text { citroen }(\mathrm{JC}) \text { - Control }\end{array}$ & $\begin{array}{l}\text { C. reticulata (Blanko) vr } \\
\text { Keprok Batu } 55\end{array}$ & 100 & 14 \\
\hline Combination 2 & $\begin{array}{l}\text { Rootstock Japansche } \\
\text { citroen (JC) - Control }\end{array}$ & $\begin{array}{l}\text { C. nobilis vr Siam } \\
\text { Pontianak }\end{array}$ & 100 & 14 \\
\hline Combination 3 & $\begin{array}{l}\text { Rootstock Japansche } \\
\text { citroen }(\mathrm{JC}) \text { - Control }\end{array}$ & $\begin{array}{l}\text { C. aurantifolia vr Sweet } \\
\text { lime }\end{array}$ & 100 & 15 \\
\hline Combination 4 & Carrizo citrange & $\begin{array}{l}\text { C. reticulata (Blanko) vr } \\
\text { Keprok Batu } 55\end{array}$ & 100 & 16 \\
\hline Combination 5 & Carrizo citrange & $\begin{array}{l}\text { C. nobilis vr Siam } \\
\text { Pontianak }\end{array}$ & 100 & 14 \\
\hline Combination 6 & Carrizo citrange & $\begin{array}{l}\text { C. aurantifolia vr Sweet } \\
\text { lime }\end{array}$ & 100 & 14 \\
\hline Combination 7 & Swingle citrumello & $\begin{array}{l}\text { C. reticulata (Blanko) vr } \\
\text { Keprok Batu } 55\end{array}$ & 100 & 12 \\
\hline Combination 8 & Swingle citrumello & $\begin{array}{l}\text { C. nobilis vr Siam } \\
\text { Pontianak }\end{array}$ & 100 & 16 \\
\hline Combination 9 & Swingle citrumello & $\begin{array}{l}\text { C. aurantifolia vr Sweet } \\
\text { lime }\end{array}$ & 100 & 14 \\
\hline Combination 10 & Poncirus trifoliata & $\begin{array}{l}\text { C. reticulata (Blanko) vr } \\
\text { Keprok Batu } 55\end{array}$ & 100 & 17 \\
\hline Combination 11 & Poncirus trifoliata & $\begin{array}{l}\text { C. nobilis vr Siam } \\
\text { Pontianak }\end{array}$ & 100 & 14 \\
\hline Combination 12 & Poncirus trifoliata & $\begin{array}{l}\text { C. aurantifolia vr Sweet } \\
\text { lime }\end{array}$ & 100 & 12 \\
\hline Combination 13 & Citrus volkameriana & $\begin{array}{l}\text { C. reticulata (Blanko) vr } \\
\text { Keprok Batu } 55\end{array}$ & 100 & 18 \\
\hline Combination 14 & Citrus volkameriana & $\begin{array}{l}\text { C. nobilis vr Siam } \\
\text { Pontianak }\end{array}$ & 50 & 21 \\
\hline Combination 15 & Citrus volkameriana & $\begin{array}{l}\text { C. aurantifolia vr Sweet } \\
\text { lime }\end{array}$ & 100 & 20 \\
\hline Combination 16 & Citrus jambhiri vr RL & $\begin{array}{l}\text { C. reticulata (Blanko) vr } \\
\text { Keprok Batu } 55\end{array}$ & 100 & 19 \\
\hline Combination 17 & Citrus jambhiri vr RL & $\begin{array}{l}\text { C. nobilis vr Siam } \\
\text { Pontianak }\end{array}$ & 50 & 18 \\
\hline Combination 18 & Citrus jambhiri6 vr RL & $\begin{array}{l}\text { C. aurantifolia vr Sweet } \\
\text { lime }\end{array}$ & 50 & 19 \\
\hline Combination 19 & Troyer citrange & $\begin{array}{l}\text { C. reticulata (Blanko) vr } \\
\text { Keprok Batu } 55\end{array}$ & 100 & 19 \\
\hline Combination 20 & Troyer citrange & $\begin{array}{l}\text { C. nobilis vr Siam } \\
\text { Pontianak }\end{array}$ & 100 & 20 \\
\hline Combination 21 & Troyer citrange & $\begin{array}{l}\text { C. aurantifolia vr Sweet } \\
\text { lime }\end{array}$ & 100 & - \\
\hline Combination 22 & Citrus kumquat vr Kanci & $\begin{array}{l}\text { C. reticulata (Blanko) vr } \\
\text { Keprok Batu } 55\end{array}$ & 100 & 16 \\
\hline Combination 23 & Citrus kumquat vr Kanci & $\begin{array}{l}\text { C. nobilis vr Siam } \\
\text { Pontianak }\end{array}$ & 50 & 25 \\
\hline Combination 24 & Citrus kumquat vr Kanci & $\begin{array}{l}\text { C. aurantifolia vr Sweet } \\
\text { lime }\end{array}$ & 50 & - \\
\hline
\end{tabular}

Severity of Disease Symptoms. The symptoms of the disease were marked by brownish areas and/or yellow exudate (gum) secretion from the point of inoculation so that 
the surface becomes wet and sticky. Another symptom of this disease is the appearance of cracks around the wound area in which the wound becomes rotten in white and discolored to brown (Figure 2). From the observation, it is known that most of the rotten stems (most extensive areas of the rot) are found in the treatment 1). JC/Carrizo citrange/C.reticulata (Blanko) K Stone 55; 2). JC/Carrizo citrange/C. aurantifolia vr Sweet Lime; 3). JC/Swingle citrumello/K Stone 55; 4). JC/Poncirus trifoliata/C. reticulata (Blanko) K Stone 55; and 5). JC/Poncirus trifoliata/C. aurantifolia vr Sweet lime with a width between 5.08 to $6.15 \mathrm{~cm}^{2}$. The width is different from other treatments. All of those five treatments were included in the moderate severity group $\left(>5\right.$ to $\left.10 \mathrm{~cm}^{2}\right)$. The treatment classified in mild severity group ( 1 to $5 \mathrm{~cm}^{2}$ ) was the most common group of 11 treatment combinations with a mean value of 1.53 $-3.25 \mathrm{~cm}^{2}$. This is lower than those 5 treatment combinations which have moderate severity but higher and significantly different than the 4 combinations of tolerant group treatments. The combination of interstock treatment JC/volkameriana/C. aurantifolia $\mathrm{vr}$ Treatment Sweet lime; JC/Troyer citrange/C. reticulata (Blanko) vr Tangerine Rock 55; JC/Troyer citrange/C. aurantifolia vr Lemon Sweet and JC/Citrus kumquat vr Kanci/C. aurantifolia vr Sweet lime showed that there are no symptoms until 16 weeks after inoculation so that it can be classified to the tolerant group (table 3).

The rootstock resistance of Troyer citrange in this study is similar to that have been mentioned by Mulaa et al., 2011 from the results of the research (2006 to 2008) concerning the tolerance of pests or diseases called as the combination of 'Troyer Citrange'/'Washington Navel 39'. In addition, (Mulaa et al., 2011) also found a tolerance on other rootstocks such as 'Rough Lemon'/'Washington Navel 102', 'Citrumello 4475'/'Washington Navel 205', 'Citrumello 4475'/Washington Navel 216', and 'Carrizo Citrage'/'Washington Navel 205. On the other hand, (Widyaningsih et al., 2017) mentioned that there is a similarity on the results of volkameriana that is more tolerant to CVPD or HLB rather than JC. It is also mentioned that the use of a mixture of rootstock and scion will increase the tolerance against HLB.

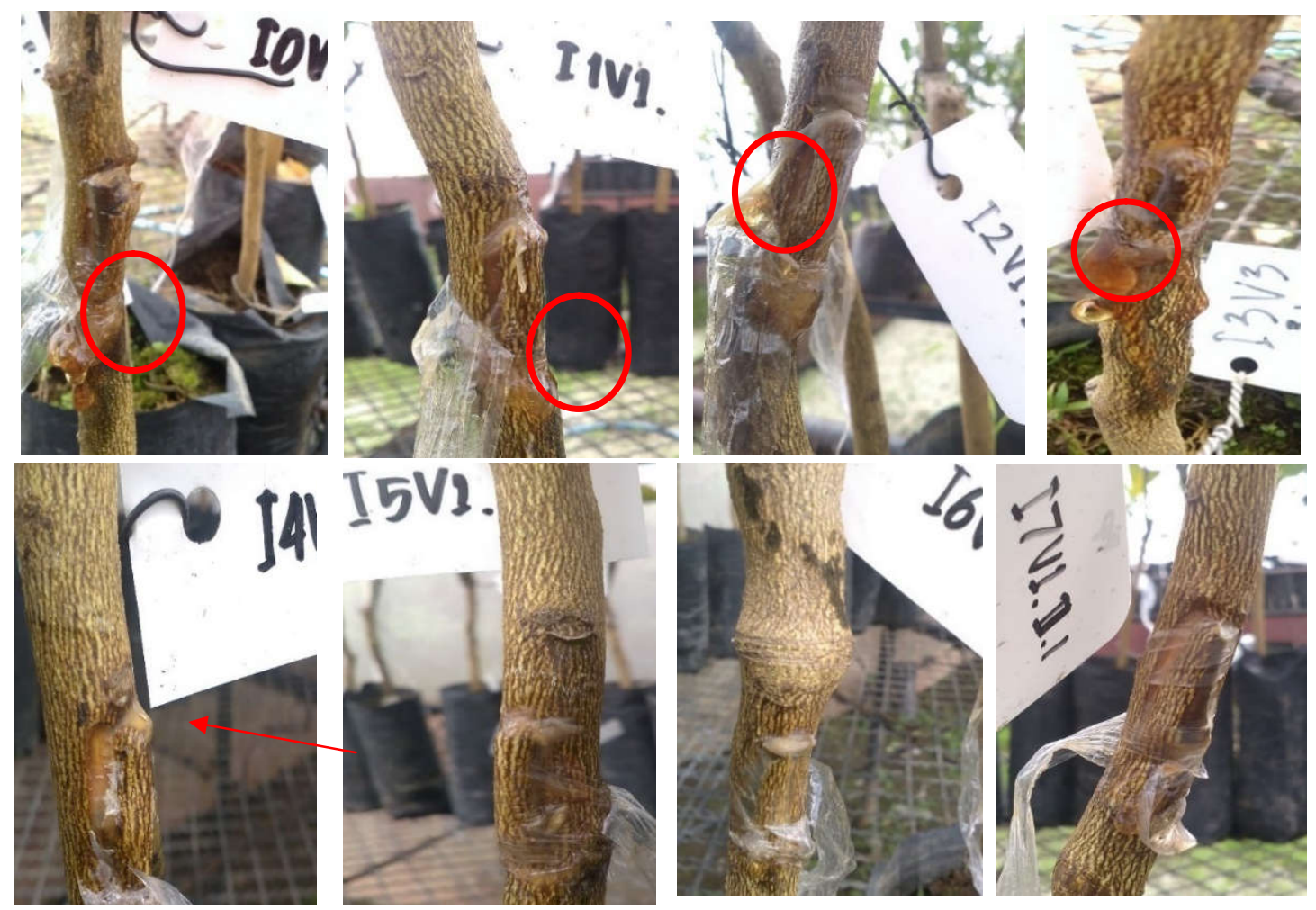

Figure 2 - The plant's performance of 8 interstocks inoculated with B.theobromae,

3 weeks after inoculation: a). Without interstock, b). Carrizo citrange interstock, c), citrumello interstock, d). Poncirus trifoliata, e). Volkameriana, f). Citrus Jambhiri, g). Troyer citrange, h). Citrus kumquat vr Kanci. = Gum, = Early rotten stem symptoms, pathogenic fungi develop in between the point of inoculation 
As we can see, the penetration of $B$. theobromae into the plant tissue is helped by the wounds inducing the production of enzymes and pathogenic toxins. The main enzymes produced by B.theobromae are $\beta$ glucosidase and cellulase which are used to soften the citrus trunk tissue while toxins are used to kill plant cells. The presence of toxins affects the permeability of cell membranes by inactivating and inhibiting plant enzymes or stopping the activity of the related plant enzymes.

Table 3 - The average of disease severity between the citrus combinations until 16 weeks after inoculation

\begin{tabular}{|c|c|c|c|c|}
\hline Combination & Interstock & Scion & $\begin{array}{l}\text { Average rotten areas } \\
(\mathrm{cm} 2)\end{array}$ & $\begin{array}{l}\text { Severity } \\
\text { group }\end{array}$ \\
\hline 1 & 2 & 3 & 4 & 5 \\
\hline Combination 1 & $\begin{array}{l}\text { Rootstock Japansche citroen } \\
\text { (JC) - Control }\end{array}$ & $\begin{array}{l}\text { C. reticulata (Blanko) vr } \\
\text { Keprok Batu } 55\end{array}$ & $6.12 \mathrm{a}$ & Moderate \\
\hline Combination 2 & $\begin{array}{l}\text { Rootstock Japansche citroen } \\
\text { (JC) - Control }\end{array}$ & C. nobilis vr Siam Pontianak & $5.48 \mathrm{a}$ & moderate \\
\hline Combination 3 & $\begin{array}{l}\text { Rootstock Japansche citroen } \\
\text { (JC) - Control }\end{array}$ & C. aurantifolia vr Sweet lime & $6.15 \mathrm{a}$ & moderate \\
\hline Combination 4 & Carrizo citrange & $\begin{array}{l}\text { C. reticulata (Blanko) vr } \\
\text { Keprok Batu } 55\end{array}$ & $5.78 \mathrm{a}$ & moderate \\
\hline Combination 5 & Carrizo citrange & C. nobilis vr Siam Pontianak & $2.70 \mathrm{~b}$ & mild \\
\hline Combination 6 & Carrizo citrange & C. aurantifolia vr Sweet lime & $5.70 \mathrm{a}$ & moderate \\
\hline Combination 7 & citrumello & $\begin{array}{l}\text { C. reticulata (Blanko) vr } \\
\text { Keprok Batu } 55\end{array}$ & $5.63 \mathrm{a}$ & moderate \\
\hline Combination 8 & citrumello & C. nobilis vr Siam Pontianak & $2.43 \mathrm{~b}$ & mild \\
\hline Combination 9 & citrumello & C. aurantifolia vr Sweet lime & $1.43 \mathrm{~b}$ & mild \\
\hline Combination 10 & Poncirus trifoliata & $\begin{array}{l}\text { C. reticulata (Blanko) vr } \\
\text { Keprok Batu } 55\end{array}$ & $3.25 \mathrm{~b}$ & mild \\
\hline Combination 11 & Poncirus trifoliata & C. nobilis vr Siam Pontianak & $5.08 \mathrm{a}$ & moderate \\
\hline Combination 12 & Poncirus trifoliata & C. aurantifolia vr Sweet lime & $5.35 \mathrm{a}$ & moderate \\
\hline Combination 13 & volkameriana & $\begin{array}{l}\text { C. reticulata (Blanko) vr } \\
\text { Keprok Batu } 55\end{array}$ & $1.53 \mathrm{~b}$ & mild \\
\hline Combination 14 & volkameriana & C. nobilis vr Siam Pontianak & $1.78 \mathrm{~b}$ & mild \\
\hline Combination 15 & volkameriana & C. aurantifolia vr Sweet lime & $0.00 \mathrm{c}$ & tolerant \\
\hline Combination 16 & Rough lemon & $\begin{array}{l}\text { C. reticulata (Blanko) vr } \\
\text { Keprok Batu } 55\end{array}$ & $3.88 \mathrm{~b}$ & mild \\
\hline Combination 17 & Rough lemon & C. nobilis vr Siam Pontianak & $3.43 \mathrm{~b}$ & mild \\
\hline Combination 18 & Rough lemon & C. aurantifolia vr Sweet lime & $2.80 \mathrm{~b}$ & mild \\
\hline Combination 19 & Troyer citrange & $\begin{array}{l}\text { C. reticulata (Blanko) vr } \\
\text { Keprok Batu } 55\end{array}$ & $0.00 \mathrm{c}$ & tolerant \\
\hline Combination 20 & Troyer citrange & C. nobilis vr Siam Pontianak & $1.98 \mathrm{~b}$ & mild \\
\hline Combination 21 & Troyer citrange & C. aurantifolia vr Sweet lime & $0.00 \mathrm{c}$ & tolerant \\
\hline Combination 22 & Citrus kumquat vr Kanci & $\begin{array}{l}\text { C. reticulata (Blanko) vr } \\
\text { Keprok Batu } 55\end{array}$ & $5.38 \mathrm{a}$ & moderate \\
\hline Combination 23 & Citrus kumquat vr Kanci & C. nobilis vr Siam Pontianak & $2.88 \mathrm{~b}$ & mild \\
\hline Combination 24 & Citrus kumquat vr Kanci & C. aurantifolia vr Sweet lime & $0.00 \mathrm{c}$ & tolerant \\
\hline
\end{tabular}

Successfully grafted seedlings were arranged in a randomized complete block design with two replications. Severities grouping on seedling: no symptom = tolerant group, $1-5 \mathrm{~cm}=$ mild group, $>5-10 \mathrm{~cm}=$ moderate group, $>10 \mathrm{~cm}=$ severe group.

The enzymes and toxins produced by $B$. theobromae are used to penetrate the point of infection located in the epidermis and parenchyma cells (Al-Saadoon et al., 2012; Parthasaranthy et al., 2016, Umeruzike, 1979). It is suspected that 4 tolerant group treatments with the interstock of Volkameria, Troyer, and Kanci which are connected above $\mathrm{JC}$ tend to have a mechanical resistance that inhibits the production of enzymes and pathogenic toxins, especially in the sweet lime.

The development of rotten stem symptoms by the treatment of several interstocks on each scion of K.Batu 55, Siam Pontianak, and Sweet lime for 5 to 16 weeks after inoculation is presented in Figures 3, 4, and 5. The treatment with the scion of $K$. Batu 55 without interstock showed the highest rod development. The trend itself is increased during the time of observation compared to other treatments (Figure 3) and then followed by the treatment with Citrumello and Poncirus trifoliata. The treatment that produced the narrowest rotten stem area was found on the RL interstock. In RL interstock, the trend was also decreased until end of the observation. 


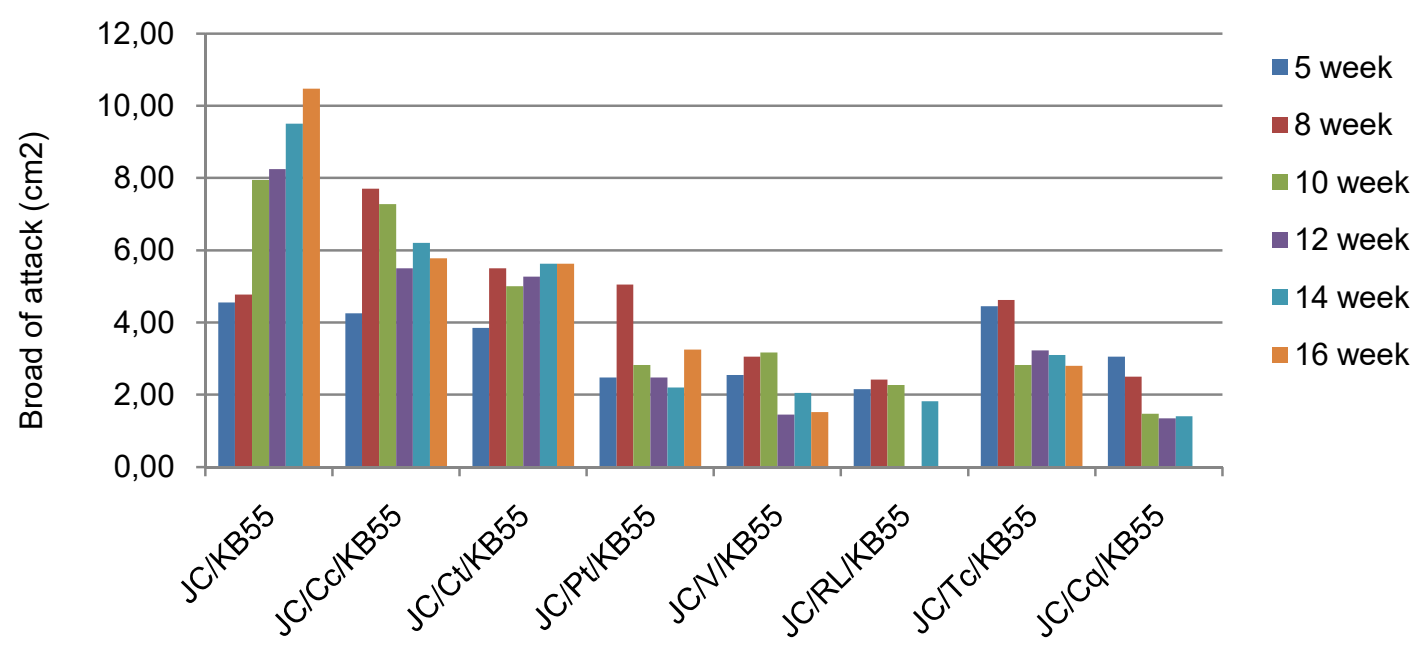

Treatment

Figure 3 - Figure 3. The development of rotten stem area $(\mathrm{cm})$ with several interstocks on Keprok Batu 55 scion at 5 to 16 weeks after inoculation

In the treatment with the scion of Siam Pontianak and Sweet Lime without interstock, the highest stem rot development is found. Also, the trend is known to be increased during the time of observation compared to other treatment (Figures 4 and 5). The combination of Troyer citrange interstock with Siam Pontianak produces the narrowest rotten stem are and decreases the trend compared to other treatments. At the end of observation, there is a healing and no symptoms occur. The development of rotten stem in other treatments looks volatile (some might stagnant, increased, or decreased).

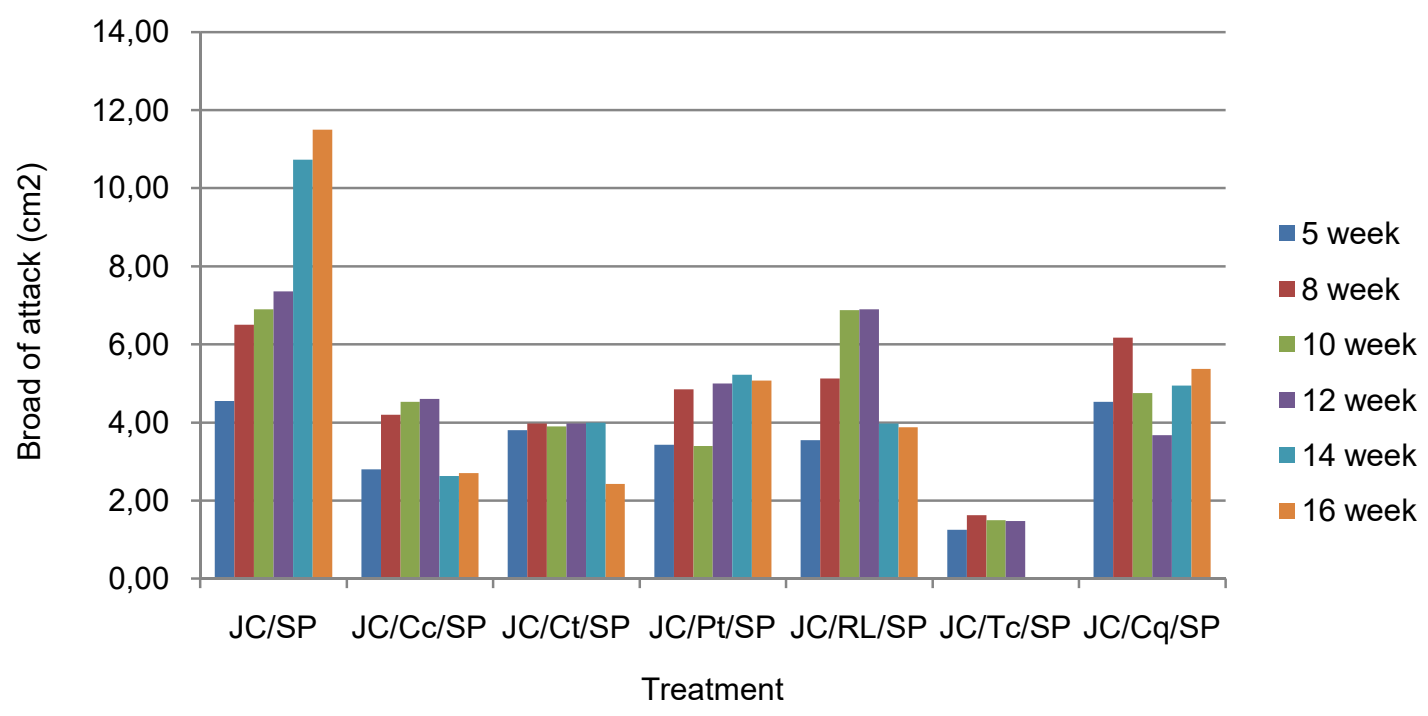

Figure 4 - The development of rotten stem area $(\mathrm{cm})$ with several interstocks on Siam Pontianak scion at 5 to 16 weeks after inoculation

On the treatment with Sweet Lime scion, there are 3 types of interstocks used such as Volkameriana, Troyer citrange, and Kanci. It is found that there are no symptoms from start to finish. All of the three interstocks can be grouped into the tolerant group (figure 5). The development of the disease with P.trifoliata interstock tends to rise very slowly while the treatment with Carizo citrange seems to produce a stagnant result. Last but not least, Citromello and $R L$ tend to decrease the disease attack. 


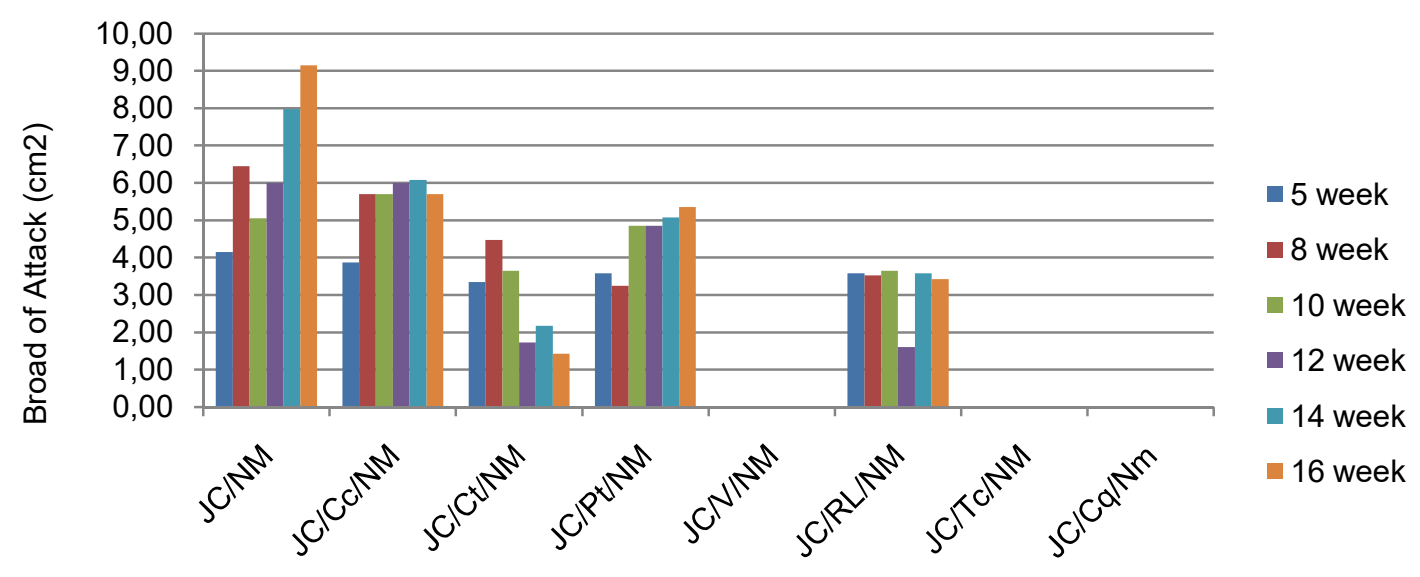

Treatment

Figure 5 - The development of rotten stem area $(\mathrm{cm})$ with several interstocks on sweet lime scion at 5 to 16 weeks after inoculation

Plant Growth. The results of the analysis of variance indicate that plant height is not significantly influenced by scion interaction and interstock usage. The average height of Keprok Batu 55 varieties on various interstock treatments has a plant height of $79.06 \mathrm{~cm}$. It tends to be higher than the height of Siam Pontianak and Sweet Lime in various treatments. The height of the scion of Siam Pontianak and Sweet Lime is $75.94 \mathrm{~cm}$ and $66.73 \mathrm{~cm}$. The differences in scion are believed due to the genetic differences of the scion itself. Makmur (1992) stated that genetic variation occurs as a cause that plants have different genetic characteristics.

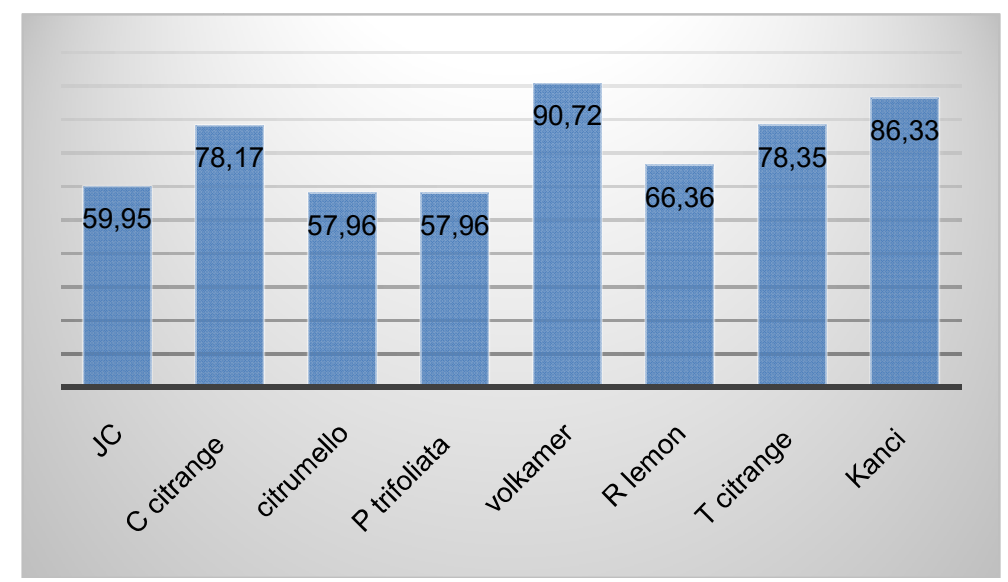

Figure 6 - Average Plant Height of several interstock at 23 weeks after inoculation, $\mathrm{cm}$

Plants joined to the Volkameriana interstock tend to be higher than the other 6 interstocks. The plant height of Volkameriana, Carizo citrange, Troyer citrange, and rough lemon is $90.72 \mathrm{~cm}, 86.33 \mathrm{~cm}, 78.17 \mathrm{~cm}, 78.35 \mathrm{~cm}$, and $66.35 \mathrm{~cm}$ respectively. The shortest plant height is found on Citromello and P.trifoliata $(57.6 \mathrm{~cm})$ (Figure 6). However, the results of this study differ from the research from Susanto et al. (2004) saying that Citrumelo and Troyer can stimulate the growth of Cikoneng Pamelo.

The main benefits of interstock that can control the growth of the scion also become the substantial factor in the development of citrus cultivation in regulating the density of plants in the field. Short plants will ease the cultivation techniques such as spraying, pruning, harvesting, and others. The use of interstock is also able to overcome the incompatibilities between scion and rootstock. 
At 23 weeks after inoculation, the Siam Pontianak which was grafted with the interstock of Citromello and $P$. Trifoliata, as well as the Sweet Lime which was joined with the interstock of Rough lemon, has the shortest plant height which was $58.25 \mathrm{~cm}, 58.55 \mathrm{~cm}$, and $60.70 \mathrm{~cm}$. The tallest plant height was obtained by Keprok Batu 55 which was connected with the interstock of Carrizo Citrange and Volkameriana as well as Siam Pontianak which was joined with Volkameriana and then Siam Pontianak and Sweet Lime which were grafted with Kanci $(88.15 \mathrm{~cm}, 96.44 \mathrm{~cm}, 90.92 \mathrm{~cm}, 93.4 \mathrm{~cm}$, and $89.4 \mathrm{~cm}$ respectively) (Table 4$)$.

Table 4 - Mean comparison of citrus plant height combination using the Duncan multiple range test

\begin{tabular}{|l|l|l|}
\hline Interstock & Scion & Plant height (cm) \\
\hline Rootstock Japansche citroen (JC) - Control & C. reticulata (Blanko) vr Keprok Batu 55 & $78.25 \mathrm{~b}$ \\
\hline Rootstock Japansche citroen (JC) - Control & C. nobilis vr Siam Pontianak & $77.41 \mathrm{~b}$ \\
\hline Rootstock Japansche citroen (JC) - Control & C. aurantifolia vr Sweet lime & $70.43 \mathrm{c}$ \\
\hline Carrizo citrange & C. reticulata (Blanko) vr Keprok Batu 55 & $88.15 \mathrm{a}$ \\
\hline Carrizo citrange & C. nobilis vr Siam Pontianak & $78.05 \mathrm{~b}$ \\
\hline Carrizo citrange & C. aurantifolia vr Sweet lime & $68.31 \mathrm{c}$ \\
\hline citrumello & C. reticulata (Blanko) vr Keprok Batu 55 & $65.73 \mathrm{c}$ \\
\hline citrumello & C. nobilis vr Siam Pontianak & $58.25 \mathrm{~d}$ \\
\hline citrumello & C. aurantifolia vr Sweet lime & $53.12 \mathrm{e}$ \\
\hline Poncirus trifoliata & C. reticulata (Blanko) vr Keprok Batu 55 & $65.10 \mathrm{c}$ \\
\hline Poncirus trifoliata & C. nobilis vr Siam Pontianak & $58.55 \mathrm{~d}$ \\
\hline Poncirus trifoliata & C. aurantifolia vr Sweet lime & $50.25 \mathrm{e}$ \\
\hline volkameriana & C. reticulata (Blanko) vr Keprok Batu 55 & $96.44 \mathrm{a}$ \\
\hline volkameriana & C. nobilis vr Siam Pontianak & $90.92 \mathrm{a}$ \\
\hline volkameriana & C. aurantifolia vr Sweet lime & $84.80 \mathrm{ab}$ \\
\hline Rough lemon & C. reticulata (Blanko) vr Keprok Batu 55 & $66.90 \mathrm{c}$ \\
\hline Rough lemon & C. nobilis vr Siam Pontianak & $71.50 \mathrm{bc}$ \\
\hline Rough lemon & C. aurantifolia vr Sweet lime & $60.70 \mathrm{~d}$ \\
\hline Troyer citrange & C. reticulata (Blanko) vr Keprok Batu 55 & $81.5 \mathrm{~b}$ \\
\hline Troyer citrange & C. nobilis vr Siam Pontianak & $83.5 \mathrm{~b}$ \\
\hline Troyer citrange & C. aurantifolia vr Sweet lime & $70.05 \mathrm{c}$ \\
\hline Citrus kumquat vr Kanci & C. reticulata (Blanko) vr Keprok Batu 55 & $93.4 \mathrm{a}$ \\
\hline Citrus kumquat vr Kanci & C. nobilis vr Siam Pontianak & 89.4 a \\
\hline Citrus kumquat vr Kanci & C. aurantifolia vr Sweet lime & $76.2 \mathrm{c}$ \\
\hline
\end{tabular}

Different letters are significantly different and means followed by the same letters are not significantly different at $P=0.05$. A total of 48 successful grafted seedlings were arranged in a randomized complete block design with Two replications.

\section{CONCLUSION}

In general, it is found that there are 3 groups resistance to $B$ theobromae combination of interstock. The first is a tolerant group: Sweet Lime scion with the interstock of Volkameriana, Troyer citrange, and Kanci have the smallest attack area $(0 \mathrm{~cm} 2)$. The second one is a group that is quite resistant to mild attack: Siam Pontianak scion with the interstock of Carrizo citrange, Citrumello, Poncirus trifoliata, Volkameriana, Rough lemon; sweet lime scion with the interstock of citrumello, Rough lemon and Keprok Batu 55 scion with the interstock of volkameriana and Rough lemon have the incubation period of 14 to 25 days after inoculation. Lastly, the group that has light resistant with moderate severity: The scion of Keprok Batu 55 with the interstock of Carrizo citrange, Swingle citrumello, Poncirus trifoliata as well as Sweet Lime scion with the interstock of Carrizo citrange and Poncirus trifoliata has an incubation period of 12 to 16 days after inoculation. The plants grafted with the interstock of Volkameriana are taller than the plants which are joined with the interstock of Citromello and P.trifoliata. 


\section{REFERENCES}

1. Adandonon A, Datinon B, Baimey J, Toffa J. 2014. First report of Lasiodiplodia theobromae (Pat.) Griffon \& Maubl. Causing root rot and collar rot disease of Jatropha curcas L. in Benin. J Appl Biosci. 79(1):6873-6877.

2. Al-Saadoon AH, Amen MKM, Al-Rubaie EMA. 2012. Histopathology of grapevine inoculated with Lasiodiplodia theobromae. Basrah J of Agric Sci. 25(1):1-12.

3. CAB International. (2007). Crop Protection Compendium. Wallingford, UK: CAB International. www.cabicompendium.org/cpc.

4. Dwiastuti, ME, Budiarta, GNK, Soesanto, L. 2017. Perkembangan Penyakit Diplodia Pada Tiga Isolat Botryodiplodia Theobromae Path Dan Peran Toksin Dalam Menekan Penyakit Pada Jeruk (Citrus Spp.) [Diplodia Disease Development And Toxin Of Three Isolates Botryodiplodia Theobromae Path. On Citrus (Citrus Spp.)] J. Hort. Vol. 27 No. 2, Desember 2017: 231-240.

5. Febbiyanti1, T R; Kusdiana APJ, , Wiyono, S, Yahya, S, and Widodo. 2017. Pathogenicity Test Of Lasiodiplodia Theobromae Isolates From Six Host Plants On Rubber And Their Phylogeny Analysis. Proceedings of International Rubber Conference 2017: 477-491M.

6. Garcia-Sanchez, F. and J.P. Syvertsen. 2009. Substrate type and salinity affect growth allocation, tissue ion concentrations, and physiological responses of Carrizo citrange seedlings. HartScience 44:432-437

7. Gimeno, V., J.P. Syvertsen, M. Nieves, I. Simon, V. Martinez, and F. Garcia-Sanchez. 2009a. Additional nitrogen fertilization affects salt tolerance of lemon trees on different rootstocks. Sci. Hort. 121:298-305.

8. Gimeno, V., J.P. Syvertsen, M. Nieves, I. Simon, V. Martinez, and F. Garcia-Sanchez. $2009 \mathrm{~b}$. Orange varieties as interstocks increase the salt tolerance of lemon trees. J. Hort. Sci. Biotechno!. 84:625-631.

9. Gil-Izquierdo, A., M.T. Riquelme, I. Porras, and F. Ferreres. 2004. Effect of the rootstock and interstock grafted in lemon tree (Citrus limon L. Burm.) on the flavonoid content of lemon juice. J. Agr. Food Chern. 52:324- 331

10. Haggag WM, Nofal MA (2006) Improving the biological control of Botryodiplodia disease on some Annona cultivars using single or multi-bioagents in Egypt. Biol Control 38:341349.

11. Dieback of walnut causing by Botryodiplodia theobromae in Egypt. Haggag, Wafaa, M. , M.S.M. Abou Rayya and N.E. Kasim (2006). First record of Botryodiplodia theobromae associated with walnut in Egypt. Plant Diseases: (USA): 91: 2 . 226

12. Khanzada, MA, Qayoom, A, And, R \& Shahzad, S 2006, 'Effect of medium, teemperature, light and inorganic fertilizers on in vitro growth and sporulation of Lasiodiplodia theobromae isolated from mango', Pak. J. Bot, vol. 38, no. 3, pp. 885-889.

13. Krezdorn, A. H. 1978. Interstocks for tree size control in citrus. Proc. Fla. State Hort. Soc. 91:50-52. http://www.fshs.org

14. Makmur, A. 1992. Pengantar Pemuliaan Tanaman. Cetakan Ketiga. Rineka Cipta. Jakarta.

15. Mbenoun, M., Zeutsa, E. H. M., Samuels, G., Amougou, F. N., \& Nyasse, S. (2008). Dieback due to Lasiodiplodia theobromae, a new constraint to cocoa production in Cameroon. Plant Pathol, 57, 381.

16. Mulaa, A. Cherunya, J. Wanyama, A. Mugita. 2011. Screening Citrus Rootstock/Scion Combinations For Tolerance To Major Pests And Diseases In North Rift Kenya. 10.17660/ActaHortic.2011.911.22

17. Nunez, EE, Filho, F de AA, Stuchi, MES, Avilés, TC \& dos Santos-Diasa, CT 2011, 'Performance of Tahiti lime on twelve rootstocks under irrigated and non-irrigated conditions', Scientia Horticulturae, vol.129, pp. 227-231

18. Parthasarathy, S, Thiribhuvanamala, G, Faisal, PM \& Prabakar, K 2016, 'Partial characterization of toxins associated with stem end rot of mango caused by Lasiodiplodia theobromae', J. of App. and Nat. Sci., vol. 8, no. 2, pp. 559-564. 
19. Putra, D, Sulistyowati, L, Cholil, A \& Martasari, C 2013, 'Evaluasi ketahanan tanaman jeruk (Citrus sp.) Hasil fusi protoplas jeruk satsuma mandarin (Citrus unshiu) dan Jeruk siam madu (Citrus nobilis) terhadap infeksi penyakit kulit diplodia (Botryodiplodia theobromae Pat.)', J. Hama dan Penyakit Tumbuhan, vol. 1, no. 1, pp.16-26.

20. Salamiah, Badruzsaufari, Arsyad M. 2008. Jenis tanaman inang dan masa inkubasi patogen Botryodiplodia theobromae Pat. pada jeruk. J HPT Tropika 8(2):123-131.

21. Salamiah. 2009. Peranan toksin yang dihasilkan oleh Botryodiplodia theobromaedalam menimbulkan penyakit diplodia pada beberapa jenis jeruk. J HPT Tropika 9(2):158-167.

22. Shahbaz M, lqbal Z, Saleem A, Anjum MA. 2009. Association of Lasiodiplodia theobromae with different decline disorders in mango (Mangifera indica L.). Pak J Bot. 41(1):259-368.

23. Shah, M. D., Verma, K. S., Singh, K., \& Kaur, R. (2010). Morphological, pathological and molecular variability in Botryodiplodia theobromae (Botryosphaeriaceae) isolates associated with die back and bark canker of pear trees in Punjab, India. Gen. Mol. Res, 9(2), 1217-1228. Pathogenicity test of Lasiodiplodia theobromae isolates from six host plants on rubber 491.

24. Shokrollah , H, T. L. Abdullah, K. Sijam, S. N. A. Abdullah. 2011. Potential use of selected citrus rootstocks and interstocks against HLB disease in Malaysia. Journal Crop Protection 30 (2011) 521-525

25. Sugiyatno, A, Setyobudi, L, Moghfoer, M.D \& Supriyanto, A 2013b, 'Respon Pertumbuhan Tanaman Jeruk Keprok Batu 55 Pada Beberapa Interstock Melalui Metode Top Working ' Unpublished Thesis, Postgraduate Program, Universitas Brawijaya.

26. Sugiyatno A., Palupi N.E. 2017. Interstock Effect On The Growth Of Mandarin Cv Batu 55, Tangerine Cv Pontianak And Lime Cv Nimas Propagated By Grafting; pp. 239-246 . Crossref DOI: 10.18551/rjoas.2017-10.34

27. Susanto, S, Sugeru, H \& Minten, S 2010, 'Pertumbuhan vegetatif dan generatif batang atas pamelo Nambangan pada empat jenis interstock', J. Hort. Indonesia., vol.1, no.2, pp. 53-58.

28. Semangun H. 2000. Penyakit-penyakit Tanaman Hortikultura di Indonesia. Gadjah Mada University Press. Yogyakarta: Salamiah 2009

29. Susanto, S., K. Suketi., Mukhlas, 2004. Penampilan pertumbuhan jeruk besar (Citrus grandis (L.) cv. Cikoneng pada beberapa Interstock. Bul. Agron. 32(2): 7-11.

30. Verma, K, Singh, K \& Kaur, R 2010, 'Morphological, pathological and molecular variability in Botryodiplodia theobromae (Botryosphaeriaceae) isolates associated with die-back and bark cancer of pear trees in Punjab, India', funpecrp. com.br Genetics and Molecular Research Mol. Res, vol. 9, no. 92, pp. 1217-1228.

31. Widyaningsih, S, Sri Nuryani Hidayah Utami, Tri Joko \& Siti Subandiyah. 2017. Development Of Disease And Growth On Six Scion/Rootstock Combinations Of Citrus Seedlings Under Huanglongbing Pressure. Journal of Agricultural Science; Vol. 9, No. 6; 2017: 229-238. ISSN 1916-9752 E-ISSN 1916-9760. Published by Canadian Center of Science and Education

32. Umezurike GM. 1979. The Cellulolytic Enzym of Botryodiplodia theobromae Pat.:Separationnd characterization of cellulases and $\beta$ - glucosidases. 